DOI: 10.32743/nesu.cross.2020.141-147

\title{
Problems and Prospects of the Development of the System of Improvement and Landscaping in the Russian Federation Municipality "City of Magadan"
}

\author{
Vitaliy P. MIKITCHUK \\ Ph.D. (Economics)
}

Associate Professor of the Department of Economics

Institute of Digital Technologies and Economics

North-Eastern State University

6 Kommuny Str., Magadan, 685000, Russia

mikitchuk72@mail.ru

\begin{abstract}
The article addresses issues related to the development of the management of the landscaping and improvement system of the territory of the municipality located in the North-East of Russia. The purpose of current study is to analyze the existing system of management of landscaping and improvement in the municipality "City of Magadan" to determine the main problems and directions of development in this field. The article contains the framework of a systematic and integrated approach, according to which landscaping and improvement of territories are considered as a managed system that includes various aspects of the formation of a comfortable urban environment in a municipality. It analyzes the main problems of management of the landscaping and improvement in the municipality "City of Magadan". It identifies the need of introducing municipal-private partnership technologies, as well as attracting people to the processes of urban development for the further development of the system of improvement and landscaping of the territory.
\end{abstract}

Keywords: improvement; landscaping; municipality; self-government.

\section{Introduction}

The improvement of the territory of municipalities is inextricably linked to the implementation of an effective urban development policy and is one of its most important components. The tasks of local government in the field of improvement are aimed at creating healthy, comfortable and cultural living conditions for the population. Furthermore, the improvement of cities and regions solves one of the most important problems of our time - improving the urban environment and creating comfortable conditions for citizens' life.

Meanwhile, to ensure the gradual development of the urban environment, the systemic implementation of measures aimed at solving urgent problems in the field of improvement and landscaping in the territory of the municipality is of particular importance. At the same time, most of the functions in the field of the improvement and landscaping are assigned to municipal government, and most of the problems of creating a comfortable urban environment are solved by local government in conditions of severe budget constraints. However, often the problems of inefficient management of improvement are one of the most significant for citizens in assessing the activities of all state and municipal governments in general.

Under the circumstances, there is a need for the formation of effective methods, technologies and instruments for the management of improvement and landscaping of municipalities in the face of 
severe limited local budgets, which will allow authorities to implement effective urban development policies aimed at creating comfortable living conditions for the population.

Thus, the relevance of the study is due, on the one hand, to the formation of a comfortable living environment and an increase in the quality of life of the population, and, on the other hand, to the lack of effective cases of increasing the effectiveness of local authorities in the field of improvement and landscaping management. In turn, the purpose of this article is to analyze the current system of improvement and landscaping management in the municipality "City of Magadan" to determine the main problems and directions of development in this field.

\section{Methods}

The theoretical and methodological basis of the study was the framework for a systematic and integrated approach (Gladov, 2015; Kolmykova, Bulbakh 2019; Kornilova, Sayekova, 2018; Yeschina, Polyanina 2016), in which the improvement and landscaping of the territories are considered as a managed system that includes various aspects of the creation of a comfortable urban environment in a municipality.

According to our approach, "improvement of the territory" includes many elements, such as construction, reconstruction, maintenance and repair of the road network, bridges, tunnels, lighting, as well as the landscaping of urban areas, the maintenance of public toilets and the development of sanitation. In the context of this study, improvement of the territory was understood as a complex of measures for engineering preparation and safety, gardening, making a road surface, lighting, placement of small architectural forms and monumental art objects (Vakhrushev, 2017).

Based on a systematic approach, the improvement of territories includes a number of interrelated components, on the basis of which the formation of a comfortable urban environment is carried out:

- elements of engineering training;

- landscaping;

- surface conjugation;

- fencing of the territory;

- design and equipment of buildings and constructures;

- pedestrian communications and transport routes;

- small architectural forms.

In addition, it is worth noting that the systematic work on managing the improvement of municipalities includes two main directions:

1) development of the territory of the municipality;

2) the maintenance, repair and exploitation of existing urban development objects (Kornienko, Shvetsova, 2015).

Also, in the preparation of the study, the main provisions of urban management and the practice of forming smart cities used in foreign literature were used (Fanga, Yu, 2017; Letaifa, 2015; Mersal, 2016; Mueller, Drake, Allen, 2019)

Only if the systematic work on the improvement management includes not only the repair and maintenance of existing urban development objects, but also the planned development of the territories of the municipality, we can talk about the formation of the effectiveness of the authorities in creating a comfortable urban environment (Aelenei, Ferreira, Monteiro et al., 2016).

\section{Results}

When creating high-quality, comfortable and safe living conditions for citizens on the territory of Magadan, a systematic approach, which is implemented on the basis of the current activities of 
municipal authorities and the implementation of targeted programs, is applied. In this regard, the study of the processes for the management of landscaping and improvement in the city should be based on a consistent analysis: the powers and results of the municipal authorities of Magadan and other subjects of improvement management; legislative framework for the management of landscaping and improvement, including municipal and departmental programs; the current level of improvement and landscaping in Magadan.

The key municipality implementing local policy in the field of city improvement and landscaping is the Department of Construction, Architecture, Technical and Environmental Control of the City Hall of Magadan. The department carries out functions for the management of improvement in the city. Direct works in the field of improvement are carried out by individual municipal budget institutions. They include: "City operational-linear road management", "Gorsvet", "Green economy combine", as well as other organizations that implement their activities in accordance with the law.

In turn, one of the main documents in the field of improvement management is the Rules for the improvement and maintenance of the territory of the municipality "City of Magadan". So, for example, the Rules define key requirements for the maintenance of structures, buildings, urban areas in which they are located, common and adjoining territories, and the appearance of facades and fences of the corresponding buildings and structures. The Rules determine the list of works on improvement, cleaning and maintenance, the frequency of their implementation, etc. According to the statistical indicators of city improvement and landscaping management, the main emphasis by local authorities is on road maintenance. This indicator has been increasing since 2015 (Table 1).

Table 1. The main indicators of improvement and landscaping of the city of Magadan

\begin{tabular}{|c|c|c|c|c|c|}
\hline Indicator's name & 2014 & 2015 & 2016 & 2017 & 2018 \\
\hline $\begin{array}{l}\text { Road repair (including soil and yard areas), } \\
\text { thousand } \mathrm{m} 2\end{array}$ & 258.1 & 197.1 & 141.9 & 220.9 & 247.1 \\
\hline The length of illuminated roads, thousand m & 163 & 163 & 163 & 163 & 163 \\
\hline Traffic lights & 35 & 37 & 39 & 40 & 40 \\
\hline $\begin{array}{l}\text { Objects of artificial road irregularities (the } \\
\text { number of sections equipped with speed } \\
\text { bumps), units }\end{array}$ & 9 & 9 & 9 & 9 & 9 \\
\hline Planted trees and shrubs, units & 36129 & 23446 & 22106 & 7105 & 5327 \\
\hline $\begin{array}{l}\text { Installed children's towns (including small } \\
\text { architectural forms), units }\end{array}$ & 647 & 421 & 212 & 256 & 235 \\
\hline
\end{tabular}

The main work in the field of territory improvement in recent years has been carried out on the basis of the departmental target program "Improvement of the Yard Territories of the Municipality "City of Magadan" (2017-2019)", within the framework of which landscaping, lighting and asphalting of courtyards and public spaces were carried out.

Another indicator that should be noted is the area of green spaces within the city, as well as their share in the total area of urban territory within Magadan (Table 2).

Table 2. Dynamics of the share of green spaces in the total area of urban lands

\begin{tabular}{llll}
\hline Year & $\begin{array}{l}\text { The total area of urban land within } \\
\text { the city (hectare) }\end{array}$ & $\begin{array}{l}\text { The area of green spaces within } \\
\text { the city (hectare) }\end{array}$ & \% to the total area \\
\hline 2014 & 34546 & 20751 & 60.068 \\
2015 & 34546 & 17193 & 49.768 \\
2016 & 34393 & 17186 & 49.969 \\
2017 & 34393 & 17188 & 49.975 \\
2018 & 34393 & 17190 & 49.981 \\
\hline
\end{tabular}


As can be seen from the presented data, landscaping of the Magadan region is not sufficiently effective. For example, the increase of green spaces in the area is absolutely insignificant - in the period from 2015 to 2018 , it grew by only $0.3 \%$. In this regard, it becomes obvious that the authorities of Magadan at the moment cannot provide a high increase in the level of greening of the territory of the municipality.

Analysis of the management system for improvement and landscaping of Magadan allows us to identify the main problems in this area. Firstly, we are talking about a low level of scientific and methodological support for management of the improvement and landscaping of the municipality. Currently, the development of urban space is an interdisciplinary scientific and practical area, integrating research in various fields of social and economic science, technology and innovation of sciences. An analysis of the dynamics of the main indicators of the development of improvement shows that now this sphere is developing based on outdated methods and principles. In this regard, the scientific justification of urban planning and development is essential for the further development of the improvement in Magadan.

Secondly, one of the problems is the lack of financial resources, what does not allow increasing the level of improvement of urban areas. Now the funds of the municipality can only maintain the current level of improvement and landscaping of the city. It can be said that municipal governments are currently unable to attract additional funds from extrabudgetary funds in the field of improvement.

Thirdly, the insufficient level of involvement of citizens in urban development processes, including the management of the improvement of the municipality. The urban community is one of the main subjects for the development of municipal improvement. Self-organization of citizens in solving important urban problems in city landscaping and improvement can significantly reduce the burden on municipal governments.

Of particular importance is the lack of involvement of the population in the management of development processes of the city. To date, the approach, according to which citizens should act as full-fledged subjects of the system of improvement and landscaping of territories, is becoming particularly relevant.

\section{Discussion}

One of the most serious problems is the insufficient level of involvement of the population in solving the problems of improvement and landscaping. As we have already noted, in Magadan there is insufficient involvement of citizens in the management of urban improvement and landscaping. In turn, the lack of public control and participation in this field is determined, first of all, by the lack of conditions for the implementation of such public initiatives and the lack of incentives by local authorities.

Magadan residence should be directly involved in the management of landscaping and urban improvement. There are several relevant fields for enhancing the participation of residents of the municipality in the urban development. The first of them is support for the activities of territorial public self-governments, partnerships of homeowners and councils of apartment buildings. To date, support for such forms of self-organization of citizens lies in the methodological and advisory support of the creation and functioning of such organizations, as well as in the financing of projects on a grant basis. Advisory and methodological support is carried out with the aim of effective selforganization of citizens and includes assistance in the preparation and registration of the statute, compliance with the necessary legal and bureaucratic procedures, and preparation of all necessary documents. Among the most modern and effective technologies for improving the effectiveness of advisory support for self-organization of citizens is the creation of a specialized organization which main function is to accompany public initiatives. Resource centers of supporting local self- 
government and associations of public self-government can be attributed to examples of such organizations. It should be noted that resource centers of supporting local public self-government are already successfully operating in several regions of Russia.

Turning to financial support for the activities of various forms of self-organization of citizens, it should be noted that the main emphasis should be placed on fundraising from the federal budget in the regions and the municipality. Due to the strict limited regional budgets, promising landscaping projects, developed at the initiative of the population, often simply cannot be implemented. Moreover, municipalities often do not have the ability to support such projects. At the same time, to date, mechanisms of supporting promising social projects in the regions of Russia are being formed at the federal level. This is, for example, the Presidential Grants Fund, which regularly provides grant support for non-profit organizations. The total annual amount of financial support is more than 8 billion rubles. In recent years, a trend has emerged, according to which financial support is received not only by socially oriented non-profit organizations, but also by territorial public selfgovernments. So, for the second grant competition in 2020, more than 500 initiative applications were submitted from territorial public self-governments from Russian regions.

Thus, one of the key tasks of city governments is to intensify the activities of territorial public selfgovernments for participation in various grant competitions and to attract additional funds to the municipality from the regions. However, it should be noted that at present, only organizations registered as legal entities can participate in grant competitions of the President of the Russian Federation, however, to date, not all territorial public self-governments of Magadan are legal entities, despite the fact that this status provides a number of advantages for their functioning. In this regard, the municipality should facilitate the official registration of territorial public selfgovernments of the city.

Another important field is the involvement of territorial public self-governments, partnerships of homeowners, street committees and councils of apartment buildings in the development and formation of regional and municipal programs for landscaping, improvement and creating a comfortable urban environment. As a rule, such programs are developed as soon as possible and do not include public discussion and evaluation. The subsequent inclusion of citizens' initiatives in these programs seems to be very difficult. In this regard, municipal authorities should create a mechanism for attracting initiative citizens to the process of developing programs for creating a comfortable urban environment and filling it with projects in the field of landscaping and urban improvement.

Thus, the mayor's office of Magadan should increase opportunities for participation in urban development for the population. In our opinion, this package of measures should include the following elements.

1. On the site of the city hall (or through a questionnaire study of the population on the city streets) organize a survey of residents of Magadan in order to identify the most important problems in the field of urban improvement, as well as identify priority, in the opinion of the population, directions of urban space development.

2. Regularly involve residents of the city, representatives of enterprises and organizations of the municipality, members of territorial public self-governments in organizing the renovating in the city territory. It is advisable to plant trees, flowers, shrubs throughout the city with the help of involved activists.

3. On an ongoing basis, organize competitions in Magadan for the most landscaped territory within the city for enterprises, organizations and residents of the municipality. To ensure the involvement of the city population in monitoring the results of activities in the field of gardening and improvement by voting on the website of the city hall. 
4. Create a municipal information system (portal) "Active Citizen". City Hall strives to create a constructive dialogue between the population and local governments of Magadan on specific issues of the development of the municipality.

As the next direction, we should note the introduction of technologies of municipal-private partnership in the field of urban space improvement on the territory of the city to attract additional investment in urban development projects, improve the level of improvement and create additional green spaces in the city.

Concession seems to be the most promising form for implementing municipal-private partnerships in Magadan. This instrument is widely used in accordance with federal law determining the procedure for concluding concession agreements. The most popular concession agreements at the municipal level are concessions of housing and communal services and improvement.

The third area of optimization in this field is the strengthening of organizational, methodological and scientific support for the improvement and landscaping of Magadan. The most important event in this field is the development of scientific and technical foundations for the formation and implementation of the territorial policy of urban improvement.

Thus, the main recommendations in this field should include:

- involvement of the scientific and expert community in the processes of management, planning and theoretical and methodological substantiation of city improvement and landscaping;

- creation of a service (committee, department) for the improvement of the territory in the structure of the local administration;

- development of the concept of landscaping the city.

\section{Conclusion}

To date, the management of improvement and landscaping of Magadan is comprehensive and consists of the following elements: municipal authorities of the city and other subjects of public amenities; regulatory framework for the management of improvement and landscaping, including municipal and departmental programs; technique and methodology of improvement management in the city. At the same time, the use of outdated methods and technologies, as well as the lack of consistency in the activities of government, determine a number of reasons for the low efficiency of improvement management, which include: insufficient involvement of citizens in the urban development processes, low level of scientific and methodological support for improvement management and landscaping, lack of financial resources in the city budget. To ensure an increase in the quality of life of the city's population and increase the comfort of the urban environment, it is necessary to increase the participation of citizens in the improvement and landscaping of the city, introduce municipal-private partnership technologies in the field of urban space improvement, and ensure the improvement of organizational, methodological and scientific support for the management of improvement and landscaping of Magadan.

\section{References}

Aelenei, L., Ferreira, A., Monteiro, C.S., Gomes, R., Gonçalves, H., Camelo, S., Silva, C. (2016). Smart City: A Systematic Approach towards a Sustainable Urban Transformation. Energy Procedia, 91, 970-979. https://doi.org/10.1016/j.egypro.2016.06.264

Fanga, C., Yu, D. (2017). Urban agglomeration: An evolving concept of an emerging phenomenon.
Landscape
and
Urban
Planning,
162 ,
126-136.

https://doi.org/10.1016/j.landurbplan.2017.02.014 
Gladov, A.V. (2015). Landscaping as a factor in the city improvement. Bulletin of Samara State University, 2(124), 207-215. (in Russian)

Kolmykova, M.A., Bulbakh, M.Yu. (2019). Problems of an integrated approach to the improvement of territories. Forum of young scientists, 5(33), 700-704. (in Russian)

Kornienko, O.P., Shvetsova, O.V. (2015). Green building strategy as one of the priority areas for creating comfortable living conditions in Omsk. National priorities of Russia, 2(16), 126130. (in Russian)

Kornilova, A.A., Sayekova D.Sh. (2018, May 27). Land improvement as a significant factor for creating a comfortable urban environment [Paper presentation]. In G.Yu. Gulyaev. Innovative approaches in solving the problems of modern society (Russia), Penza (pp. 275278). Science and Education. (in Russian)

Letaifa, S.B. (2015). How to strategize smart cities: Revealing the SMART model. Journal of Business Research, 68(7), 1414-1419. https://doi.org/10.1016/j.jbusres.2015.01.024

Mersal, A.D. (2016). Sustainable Urban Futures: Environmental Planning for Sustainable Urban Development. Procedia Environmental Sciences, 34, 49-61. https://doi.org/10.1016/j.proenv.2016.04.005

Mueller, M.A., Drake, D., Allen, M.L. (2019). Using citizen science to inform urban canid management. Landscape and Urban Planning, 189, 362-371. https://doi.org/10.1016/j.landurbplan.2019.04.023

Vakhrushev, V.V. (2017). Russian and foreign experience in organizing landscaping. The role and place of the population in solution to the issue of the improvement of the territory. Ways of communication between the state and the population. The concept of "improvement". Materials of the Ivanovo Readings, 1(10), 194-200. (in Russian)

Yeschina, E.V., Polyanina, A.Yu. (2016). Problems of comprehensive improvement of domestic territories of the large Russian cities. Education and science in the modern world, 4, 164172. (in Russian) 